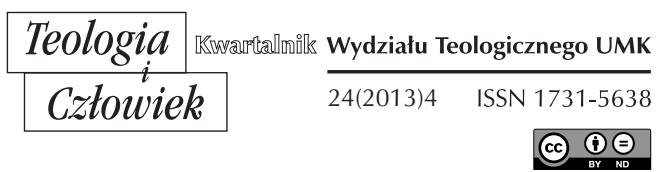

WŁADYSŁAW BLIN*

WITEBSK-BIAŁORUŚ

\title{
DOŚWIADCZENIE WIARY KOŚCIOŁA KATOLICKIEGO NA BIAŁORUSI PO 1991 ROKU
}

\section{WSTĘP}

Misja Kościoła Chrystusowego jest żywa i wciąż trwa. Powinna ona docierać do każdego człowieka, poruszając jego umysł i serce. Kościół mocą Chrystusowego mandatu musi wchodzić w każdą społeczność i docierać z Dobrą Nowiną do najdalszych zakątków świata ${ }^{1}$.

Nową wrażliwością na sprawy ewangelizacji natchnął wszystkich w Kościele Sobór Watykański II, a potem Synod Biskupów z 1974 roku i adhortacja apostolska Pawła VI o ewangelizacji w świecie współczesnym oraz dokumenty i wypowiedzi Jana Pawła VI o ewangelizacji ${ }^{2}$.

Te ważne wydarzenia w życiu Kościoła współczesnego pobudzają wszystkich do refleksji, jak ewangelizować Kościoły partykularne, łorusi.

* Ks. bp dr Władysław Blin emerytowany biskup diecezji witebskiej na Bia-

${ }^{1}$ B. Drożdż, Wychowawcza funkcja Kościoła w społeczeństwie pluralistycznym. Studium pastoralne, Legnica 1997, s. 9.

${ }^{2}$ R. Kamiński, Diecezja miejscem ewangelizacji, w: R. Kamiński, S. J. Koza, L. Skorupa, K. Święs (red.), W stużbie wartościom, Kielce 1999, s. 216. 
wspólnoty parafialne i poszczególne środowiska w obecnych uwarunkowaniach. Niniejszy artykuł zatytułowany „Doświadczenie wiary Kościoła katolickiego na Białorusi po 1991 roku" ma na celu ukazanie nowej rzeczywistości religijnej i społeczno-politycznej tego kraju.

\section{1. ŻYCIE RELIGIJNE PO PRZEMIANACH 1991 ROKU}

Życie Kościoła na Białorusi, pomimo różnych trudności stawianych przez władze komunistyczne, powoli zaczęło się rozwijać.

Spotkanie Michaiła Gorbaczowa z Ojcem Świętym było jednym z kilku wydarzeń - znaków, które świadczyły o zmianie polityki władz wobec religii. Podstawowym czynnikiem tej zmiany była postępująca degradacja państwa radzieckiego. Polityka bezwzględnej kontroli, represji coraz bardziej odchodziła w zapomnienie, albo też była unikana przez władzę centralną, a przez to i lokalną. Na fali odnowy i „wolności słowa” rozpoczął się proces odradzania się tożsamości narodowej $\mathrm{w}$ republikach radzieckich. Czynnik narodowy ściśle wiązał się z religijnym, który uważany był za element tożsamości, nawet jeśli nie miał z praktykowaniem wiary nic wspólnego ${ }^{3}$.

Coraz silniejsze tendencje niepodległościowe przyczyniły się do ogłoszenia 25 sierpnia 1991 roku Białorusi niezależnym państwem, które gwarantowało rozwój swobody sumienia, wiary i jej wyznania ${ }^{4}$.

Najważniejszym wydarzeniem w życiu odradzającego się Kościoła była nominacja 25 lipca 1989 roku przez Ojca Świętego Jana Pawła II ks. Tadeusza Kondrusiewicza ${ }^{5}$ biskupem dla katolików na Białorusi, który otrzymał tytuł administratora apostolskiego Mińska i całej Białorusi. Ogromnym świętem było wprowadzenie nowego biskupa do kościoła w Grodnie i Mińsku. Ingresy odbyły się 28 (w Grodnie) i 30 października 1989 roku (w Mińsku). W uroczystościach, oprócz tysięcy wiernych i ponad 100 kapłanów, wzięli także udział delegat Jana Pawła II, arcybiskup Francesco Colasuonno oraz biskupi z Polski i Litwy.

${ }^{3}$ Przemówienie Ojca Świętego Jana Pawła II do Michaiła Gorbaczowa, Przewodniczącego Rady Najwyższej ZSRR, w „Tygodnik Powszechny” nr 52-53 (2113-2114) 1989, s. 2.

${ }^{4}$ Wiadomości Najwyższej Rady Republiki Białoruskiej, Mińsk 1 (1992), s. 7.

${ }^{5}$ Proboszcz kościoła franciszkańskiego i fary pojezuickiej w Grodnie. Pochodził z polskiej rodziny, wsi Odelsk koło Grodna. Skończył seminarium duchowne w Kownie. 
Pierwszą troską, biskupa Kondrusiewicza, zaraz po zorganizowaniu kurii biskupiej, było zapewnienie duszpasterzy do podległych mu placówek.

Ksiądz Władysław Blin oficjalnym dekretem, wydanym dnia 15 maja 1990 roku został mianowany proboszczem parafii Mohylew (archidiecezja mińsko-mohylowska). Działalność duszpasterska nie była ograniczona tylko do samego miasta Mohylewa. Entuzjazm, wielka troska i energia owego kapłana co pewien czas poszerzała zaniedbane terytorium działalności apostolskiej. Ks. Blin systematycznie dojeżdżał do Bobrujska, Homla, Mozyra, Żłobina, Rogaczewa, Lepiela, gdzie powoli powstawały nowe parafie ${ }^{6}$.

Dnia 13 lipca 1990 roku kościół został oficjalnie zwrócony katolikom. Tym uroczystościom przewodniczył ks. bp Kondrusiewicz. Latem tego roku do pracy apostolskiej i do pomocy przy remoncie katedry przyjechali klerycy z Polski, siostry zakonne oraz grupy modlitewne, które razem z kapłanem i siostrami anielankami udawały się w różne strony Mohylewszczyzny na spotkania ewangelizacyjne ${ }^{7}$.

Wielkim przeżyciem duchowym dla parafian było procesyjne przejście w dzień Wigilii Bożego Narodzenia 1990 roku z kaplicy na cmentarzu do katedry, a właściwie do przygotowanej zakrystii, gdzie został umieszczony duży obraz Matki Bożej Białynickiej, który razem z parafianami przetrwał trudne czasy bolszewizmu. Przed katedrą po raz pierwszy zostały wystawione jasełka przez młodzież i dzieci, które powoli zapoznały się z kapłanem i parafią. 31 marca 1991 roku pierwsze Święta Wielkanocne parafianie przeżywali w zrujnowanej katedrze, pośród rusztowań. 5 maja 1991 roku 43 osoby, dzieci i młodzież od 8 do 27 lat przystąpity do pierwszej Komunii Świętej ${ }^{8}$.

W czasie wakacji 1990 roku do parafii w Mohylewie przyjeżdżało wielu kleryków nie tylko z Polski, lecz także z Belgii, Francji i Niemiec. To wielkie ożywienie życia religijnego, wśród niektórych ludzi budziło nienawiść do ks. Władysława. Zdarzyły się prowokacje i groźby. Latem 1991 roku po raz pierwszy ks. prob. Blin wysłał dwa tysiące dzieci do Polski, aby mogły zapoznać się z życiem religijnym $\mathrm{w}$ rodzinach. Niektóre z nich skorzystały z porad polskich lekarzy. Wiele dzieci osłabionych fizycznie i chorych $\mathrm{z}$ powodu wybuchu elektrowni atomowej

${ }^{6}$ Wywiad z nauczycielką Galiną Albertowną.

${ }^{7}$ Kronika parafii św. Stanisława.

8 Tamże. 
w Czarnobylu musiało swój pobyt przedłużyć. Chętnych na takie wyjazdy przybywało, jednak ze względu na braki finansowe $w$ następnych latach ograniczono liczbę wyjeżdżających dzieci. Wyjeżdżały te dzieci, które uczęszczały do niedzielnej szkoły prowadzonej przez s. Jadwigę Szczupak i s. Janinę Wojewódzką - anielanki ${ }^{9}$.

W pracy duszpasterskiej ks. Blinowi pomagało dwóch starszych emerytowanych kapłanów z Polski: ks. Zygmunt Chodosowski i ks. Bronisław Karwowski. Ks. proboszcz często musiał opuszczać parafię wyjeżdżając do Polski, Anglii i Niemiec, aby uzyskiwać pomoc na remont katedry i ewangelizacje. Przy parafii pomagały również dwie siostry orionistki z Polski, które po roku pracy przeniosły się na teren Rosji do Smoleńska. Z posługą jeździli tam również księża z Mohylewa.

Msze Święte były odprawiane w języku polskim, białoruskim i rosyjskim. Parafianie, choć nie wszyscy rozumieli po polsku, jednak najchętniej chodzili na Mszę w tym języku ${ }^{10}$.

Ksiądz proboszcz Blin, ze swoich badań, jakie prowadził do pacy naukowej z socjologii, stwierdził, że: „Im dłuższy i częstszy kontakt z księdzem, tym wyższa religijność i im większa możliwość kontaktu ze świątynią katolicką, tym więcej katolików na tym terenie". Powoli z terenu wielkiej parafii mohylewskiej powstają nowe parafie. Ks. Chodosowski i ks. Karwowski zajęli się nowymi miejscowościami: Mścisław, Szkłów, Białynicze. Do pracy w Mohylewie przyjeżdżało z pomocą okresową wielu kapłanów zakonnych i diecezjalnych ${ }^{11}$.

Po przeszło 300 latach, przy kościele, który wraz z klasztorem został zbudowany dla zakonników - czcicieli Matki Bożej z Góry Karmel, wznowione zostało Bractwo Szkaplerza Świętego. Dnia 17 sierpnia 1992 roku ks. Stefan Kulka z diecezji krakowskiej przyjął do Bractwa Szkaplerza Świętego 73 osoby. Bractwo zobowiązywało się do tego, aby 16 dnia każdego miesiąca razem gromadzić się na modlitwę ${ }^{12}$.

Pod koniec sierpnia 1992 roku na stałe do pracy w Mohylewie przyjeżdżają dwie siostry ze Zgromadzenia Sióstr Misjonarek Świętej Rodziny. Zgromadzenie to zostało zaproszone do pracy przez ks. Blina, który przypominał siostrom, że tu być powinny, gdzie zostało założone 1994, s. 19.

9 W. Blin, Dobra Nowina na wschodniej Białorusi, "Słowo”, 23-26 grudzień

\footnotetext{
${ }^{10}$ Tamże.

${ }^{11}$ Tamże.

${ }^{12}$ Księga Bractwa Szkaplerza Świetego parafii św. Stanisława, s. 4.
} 
w 1905 roku przez Bolesławę Lament i ma za swój cel realizować pragnienie Chrystusa „Aby wszyscy byli jedno”. Siostry zamieszkały w przygotowanym pokoju na wieży kościoła. S. Edwina Łęgowska zajęła się obszernie prowadzoną już korespondencją parafialną. S. Stefania Niewińska objęła pracę w zakrystii. Obie siostry razem $\mathrm{z}$ siostrami anielankami i kapłanami wyjeżdżały do pracy w teren i uczęszczały systematycznie na wykłady z języka rosyjskiego, aby móc lepiej spełniać polecone zadania.

W tym czasie pojawiają się pierwsze powołania do kapłaństwa. Choć może jeszcze nieugruntowane, są jednak znakiem odradzania się życia religijnego. Ks. proboszcz wysłał pięciu spośród nich do seminarium w Grodnie, aby tam mogli pogłębić wiarę, odszukać cel swego życia i realizować powołanie ${ }^{13}$.

Od 4 do 18 października 1992 roku w parafii odbywały się rekolekcje, które prowadzili Ojcowie Werbiści z Polski, ks. Piotr Karwacki z Białegostoku i ks. Józef Węcławik z Warszawy. Podczas trwania rekolekcji parafia obchodziła 300-lecie istnienia katedry św. Stanisława. Uroczystościom przewodniczyli ks. abp Kazimierz Świątek i bp Bronisław Dembowski z Włocławka. Na tę uroczystość przybyło 20 kapłanów z okolicznych parafii i z Polski. Przybyły również siostry z młodzieżą oraz wielu gości katolików i prawosławnych. Katedra z trudem pomieściła wszystkich przybyłych. Podczas uroczystości zostało poświęcone nowe nagłośnienie, organy ofiarowane $z$ Holandii, oraz pamiątkowy krzyż umieszczony na placu przed katedrą. Na zakończenie rekolekcji parafię Mohylewską miała nawiedzić figura MB Fatimskiej ${ }^{14}$. Okazało się jednak, że jeszcze $\mathrm{w}$ tym roku władze $\mathrm{w}$ Moskwie nie zgodziły się na peregrynację. Wierni łączyli się tylko duchowo z przelatującą do Warszawy Figurą Fatimską. Parafianie z wiarą przyjęli inną figurę, którą otrzymali jako dar z Fatimy.

Wieczorem 17 października w uroczystej procesji wokół kościoła wzięły udział dzieci w bieli przygotowane przez siostry anielanki. Milicjanci nieśli uroczyście figurę. Rozbrzmiewał śpiew i wznosiła się modlitwa dziękczynna za 300 lat tegoż kościoła. Słychać było bicie dzwonów, jeszcze nie mohylewskiej katedry, lecz nagrane z sanktuarium Matki Bożej w Licheniu ${ }^{15}$.

13 Wywiad z ks. W. Blinem.

14 300-lecie katedry św. Stanistawa, „Magilewskaja Prawda”, 09.10.1992, s. 4.

15 Obserwacje własne. 
Podczas uroczystości Białoruska Katolicka Gromada prowadziła konferencje i wystawy związane z kulturą białoruską. Przewodniczącym tej organizacji był Feliks Januszkiewicz, zaangażowany w renowacje katedry ${ }^{16}$.

13 lipca 1993 roku abp Kazimierz Świątek udzielił sakramentu bierzmowania 96 osobom. Młodzież i dorośli przygotowani zostali do tego sakramentu przez Siostry od Aniołów. Od 13 do 17 lipca tego roku odbywał się w Mohylewie, zorganizowany przez parafię I Międzynarodowy Festiwal Pieśni i Muzyki Duchowej „Mahutny Boża”"17.

7 listopada 1993 roku diecezja mińsko-mohylewska została podzielona na dekanaty. Dekanat Mohylewski objął całe województwo mohylewskie. Dziekanem i członkiem rady kapłańskiej został ks. Władysław Blin. Na Boże Narodzenie tego roku abp Świątek poświęcił nową część plebanii. W dniach 13-17 lipca 1994 roku odbył się II Międzynarodowy Festiwal pieśni religijnej. Tego roku Ojciec Święty Jan Paweł II mianował kardynałem abpa Kazimierza Świątka. Ks. Kardynał na Boże Narodzenie odbył Ingres do katedry w Mohylewie umacniając wiernych błogosławieństwem pasterskim ${ }^{18}$.

Radosnym przeżyciem $\mathrm{w}$ parafii były śluby wieczyste pracującej w parafii s. Łucji Kozakiewicz ze Zgromadzenia Sióstr Misjonarek Św. Rodziny. Dla zgromadzenia był ten rok 90. rocznicą założenia. Uroczystości tej przewodniczył ks. Kardynał Kazimierz Świątek, arcybiskup metropolita mińsko-mohylewski, administrator apostolski diecezji pińskiej. S. Łucja Kozakiewicz swoje śluby ofiarowania siebie Bogu złożyła na ręce przełożonej generalnej M. Lucjany Puciłowskiej z Polski ${ }^{19}$.

25 listopada 1995 roku w Mohylewie odbyły się uroczystości poświęcone św. Cecylii oraz obchodom 30 rocznicy zakończenia Soboru Watykańskiego II. Tym uroczystościom przewodniczył bp Bronisław Dembowski z Włocławka, który wygłosił konferencję poświęconą tym wydarzeniom. Zostały również wygłoszone referaty innych zaproszonych gości. Otwarto wystawę książek religijnych. Odbyła się w końcu prezentacja książki Jana Pawła II Przekroczyć próg nadziei przetłumaczonej na język rosyjski ${ }^{20}$.

\footnotetext{
16 300-lecie katedry..., s. 4.

17 Kronika parafialna.

${ }^{18}$ Wywiad z ks. W. Blinem.

${ }^{19}$ Kronika parafialna.

${ }^{20}$ Tamże.
} 
Dzięki staraniom ks. proboszcza, kapłanów, sióstr i wiernych świeckich w latach 1989-1995 zostały zarejestrowane następujące parafie na mohylewszczyźnie: Mohylew, Biełynicze, Mścisław, Szkłów, Faszczówka, Słabotka-Kniażyce, Czausy, Bychów, Riasna. Wszystkie te parafie obsługiwane były przez kapłanów z Mohylewa. Poza zarejestrowanymi wspólnotami dojeżdżano do wiernych w następujących miejscowościach: Krugłoje, Sławgorod, Kriczew, Czerikow, Chocimsk, Klimowicze, Krasnopole, Gorki, Kliczew, Czeczewicze. Ze względu na brak kapłanów i sióstr do tych placówek dojeżdżano dorywczo. Jednocześnie były obsługiwane wspólnoty wierzących w Susłuwce, Kościukowiczach, Popławaczynie, gdzie trwały przygotowania do rejestracji nowych parafii ${ }^{21} . w$ ostatnich latach do kapłaństwa przygotowało się czterech alumnów z Mohylewa oraz dwie kandydatki zgłosiły się do zgromadzeń zakonnych ${ }^{22}$.

Dzięki staraniom ks. proboszcza dobiegała do końca restauracja kościoła. Nabierał uroku również plac przykościelny, wyłożony kostką, udekorowany kwiatami, trawą i fontanną, która przyciągała mnóstwo dzieci. Wykończono wieże kościelne. $W$ jednej znalazły się dwie sale do lekcji religii w niedzielę i dni powszednie oraz bogata w księgozbiór biblioteka. Drugą wieżę przeznaczono na mieszkania dla księży i przyjeżdżających gości oraz na jadalnię prowadzoną przez bezinteresowną parafiankę panią Reginę $e^{23}$.

Otwartość i troska wielu kapłanów i sióstr sprawiła, że z nielicznej grupy wiernych, z którymi rozpoczynał swą pracę ks. Władysław Blin przed sześciu laty, powstała parafia licząca kilkaset osób, a „sympatyzujących" z Kościołem, jak mówi ks. proboszcz, jest około 1,5 tysiąca ludzi ${ }^{24}$.

Od roku 1995 w parafii Mohylew i Bobrujsk jest wydawana co kwartał gazetka „Wiestnik nadziei”. Zawarte zostały w niej katechezy oraz wiadomości dotyczące obu tych parafii ${ }^{25}$. W dniach 13-17 lipca 1995 roku odbył się III Festiwal Pieśni Religijnej „Mahutny Boża”, który stał się już coroczną impreza, organizowaną przez Kościół w Mohylewie ${ }^{26}$.

W 1990 roku przyjeżdżają następni ochotnicy: do Mozyra (diecezja pińska) przyjechał ks. Józef Dziekoński (z diec. warszawskiej), ks. Andrzej

\footnotetext{
${ }^{21}$ Statystyka parafialna $1995 \mathrm{r}$.

${ }^{22}$ Wywiad z ks. W. Blinem.

${ }^{23}$ Obserwacje własne.

${ }^{24}$ Wywiad z ks. W. Blinem.

${ }^{25}$ Wywiad z ks. Romanem Foksińskim, proboszczem z Bobrujska.

${ }^{26}$ Wywiad z malarzem Aleksandrem Puszkinem.
} 
Szczęsny (z diec. gnieźnieńskiej) do Bobrujska, ks. Zbigniew Bojar (sercanin) do Lelczyc, ks. Stanisław Sałata (misjonarz św. Rodziny) do Narowli, ks. Mieczysław Janczyszyn (z diec. wrocławskiej) do Lepiela, ks. Antoni Koczko (z diec. włocławskiej) do Zamościa, ks. Jan Salamon (diec. włocławska) do Swietłagorska. W końcu 1990 roku na Białorusi pracowało już 50 księży z Polski, dzięki temu zarejestrowanych było 214 parafiii ${ }^{27}$.

Przyjazd księży z Polski ożywił życie religijne ludzi wierzących. Zaczęto odzyskiwać zabrane kościoły, a tam gdzie ich nie było, budowano nowe.

Entuzjazm odrodzenia religijnego stał się tak duży, że dochodziło do odbudowy kościołów od fundamentów. Sytuację taką zaobserwowano w miejscowości Woronowo (diec. grodzieńska), gdzie buldożery kompletnie zniszczyły miejscowy kościół. Taki sam los spotkał kościół w Brzozówce (diec. grodzieńska), który przypominał ludziom o Bogu. Jak każdy inny kościół był on zaprzeczeniem propagandy ateistycznej, dlatego musiał zniknąć z powierzchni ziemi (w 1954 roku został rozebrany). Dla zatarcia wszelkich śladów na jego miejscu wybudowano hotel robotniczy. Kościół zniszczono, ale parafianie dalej strzegli wiary w sercach. Sakramenty przyjmowali w sąsiednich parafiach najczęściej w Nowogródku, gdzie był otwarty kościół. Tak było do 1991 roku, kiedy to wierzący rozpoczęli starania o zwrot zabranej ziemi. Razem z przybyłym z Polski ks. Andrzejem Stopyrą (z diec. przemyskiej), w 1992 roku rozpoczynają odbudowę kościoła, którego poświęcenie nastąpiła w roku $2001^{28}$.

W 1990 roku zaczęło się odradzać życie religijne mieszkańców miasteczka Narowla (diec. pińska). Po zniszczeniu w 1924 roku przez reżim komunistyczny kaplicy, (wybudowanej w XIX wieku), parafianie, nie patrząc na różne przeszkody, komunistyczne prześladowania, pozostali wierni Kościołowi katolickiemu. Z wiarą i nadzieją doczekali się zarejestrowania parafii w 1991 roku, której proboszczem został ks. Stanisław Sałata (misjonarz św. Rodziny). Parafii dano budynek byłego oddziału milicji, który miał krzywe ściany, wyłamane drzwi, wybite okna oraz dużo śmieci. To wszystko nie przestraszyło parafian i proboszcza. Po szybkim remoncie, budynek ten przemienił się w ładną domową kaplicę. Jednak wierzący nie przestali na tym. Marzyli o pięknym kościele. Znów

${ }^{27}$ J. Salamon, Kościót na Białorusi na progu III tysiąclecia, "Studia Włocławskie" t. 2, 1999, s. 234 .

${ }^{28}$ Notatka redakcyjna, Poświęć, czyli oddać Bogu na wyłaczna własność, „Słowo życia" nr 16, 09.09.2001, s. 9. 
się zaczęła budowa. Dzięki pomocy wierzących z Polski i Niemiec udało im się wybudować kościół Świętego Krzyża, który został poświęcony w 1998 roku przez kard. Kazimierza Świątka. To był niezapomniany moment w życiu parafian. Ludzie z radości płakali, wspominali gorycz i zniewagi za swoją wiarę oraz widzieli szczęście odrodzenia kościoła ${ }^{29}$.

Następną zasługą bpa Kondrusiewicza było otwarcie seminarium duchownego, które zostało umieszczone w odzyskanym klasztorze pobernardyńskim w Grodnie, które nastąpiło na jesieni 1990 roku. Pozwoliło to na kształtowanie miejscowego duchowieństwa, ponieważ stopniowo odzyskiwano zabrane przez władze komunistyczne kościoły, a kapłanów wciąż brakowało. Wcześniej było to niemożliwe, gdyż system komunistyczny na to nie zezwalał. W czasach komunistycznych istniały tylko dwa seminaria duchowne w Rydze (Łotwa) i w Kownie (Litwa). Chociaż były powołania na Białorusi, to jednak młodym Białorusinom nie zezwalano na wyjazdy za granice. Wszelkie próby rozmów z władzami były bezskuteczne. W Grodnie w 1990 roku są klerycy z Białorusi, Ukrainy i Rosji ${ }^{30}$.

Sytuacja Kościoła katolickiego zmieniła się: „ludzie zrozumieli, że nie muszą się bać - wspomina późniejszy kardynał Kazimierz Świątek. Zaczęto chodzić do kościoła, deklarować publicznie swoją wiarę, wiedząc, że nie ryzykuje się aresztowania czy utraty miejsca pracy. Do kościoła wróciły dzieci i młodzież. Zaczęło sie normalizować życie parafialne i sakramentalne" ${ }^{\prime \prime}$.

Czas odzyskiwania wolności powoli się kończył, rozpoczynał się okres, gdzie potrzebne były struktury, hierarchia i podjęcie systematycznej pracy nad rozwinięciem katolicyzmu w duchu odnowy soborowej.

\section{UTWORZENIE DIECEZJI I UTWORZENIE HIERARCHII KOŚCIELNEJ}

Upadek komunizmu umożliwił nominacje biskupów, a co za tym idzie - odrodzenie religijne i odbudowę struktur kościelnych na Białorusi. Mianowanie bpa Tadeusza Kondrusiewicza administratorem apostolskim na Białorusi z siedzibą w Mińsku (25 lipca 1989 r.) oznaczało początek normalizacji tamtejszego Kościoła. Została mu bowiem powierzona opieka

${ }^{29}$ R. Garodka, Kościót w Narowli, „Ave Maria” nr 7-8 (86-87) 2002, s. 30-31.

30 Z. Wietrzak, Kościót Katolicki w Europie Środkowo-Wschodniej, Kraków 1997, s. 55.

${ }^{31}$ W. Rędzoch, Przeżyt 10 lat gułagu, „Niedziela” 18.12.1994, s. 5. 
duszpasterska nie tylko nad wiernymi z Mińska, ale nad wszystkimi katolikami (ok. $2 \mathrm{mln}$ ) na terenie całej Białorusi. Jednak rozległość tego obszaru nie pozwalała jednemu biskupowi na zaspokojenie potrzeb religijnych wszystkich wiernych. Po przywróceniu wolności religijnej 13 kwietnia 1991 roku Ojciec Święty Jan Paweł II podjął decyzje o reorganizacji struktury diecezjalnej Kościoła białoruskiego. Dzięki temu do życia zostały powołane dwie diecezje: grodzieńska i pińska oraz archidiecezja mińsko-mohylewska. Biskupem Grodna został ks. Aleksander Kaszkiewicz, proboszcz Kościoła św. Ducha w Wilnie. Metropolitą Mińska-Mohylewa i administratorem diecezji pińskiej został ks. Kazimierz Świątek, proboszcz z Pińska ${ }^{32}$.

W dniu 12 listopada 1992 roku w Watykanie została ogłoszona wiadomość o nawiązaniu stosunków dyplomatycznych między Stolicą Apostolską a Republiką Białoruską: tego samego dnia w Mińsku podpisano odpowiedni protokół, przewidujący otwarcie ambasady białoruskiej przy Watykanie oraz Nuncjatury Apostolskiej w Mińsku.

18 kwietnia 1993 roku Ojciec Święty mianował abpa Gabriela Montalvo, Kolumbijczyka, dotychczas pronuncjusza w Jugosławii, nuncjuszem apostolskim na Białorusi. 12 maja w Mińsku złożył on listy uwierzytelniające przewodniczącemu Parlamentu i prezydentowi Republiki, Stanisławowi Szuszkiewiczowi, w obecności arcybiskupa mińsko-mohylewskiego i administratora apostolskiego Pińska Kazimierza Świątka oraz biskupa Grodna Aleksandra Kaszkiewicza. Wcześniej nuncjusz przewodniczył uroczystej koncelebrze $\mathrm{w}$ mińskiej katedrze, gdzie spotkał się z miejscową społecznością katolicką. Po uroczystej inauguracji swego urzędu abp Montalvo odwiedził diecezje Pińską i grodzieńską, spotykając się z kapłanami, seminarzystami i wiernymi ${ }^{33}$. Zapoznał się także z sytuacją Kościoła na Białorusi, ze strukturą diecezji.

W dniu 29 września 1998 roku diecezja grodzieńska doczekała się drugiego biskupa, którym został ks. Antoni Dziemianko ${ }^{34}$, mianowany biskupem pomocniczym. To spowodowało jeszcze większą stabilizację Kościoła w diecezji grodzieńskiej.

W dniu 24 czerwca 1999 roku diecezja pińska wzbogaciła się o jeszcze jednego biskupa. Biskupem pomocniczym został ks. Kazimierz

32 Por. „L'Osservatore Romano”, nr 12 1993, s. 58.

33 Tamże.

34 I. Makowicz, Kościót na Białorusi żyje coraz petniej, "Niedziela” nr 43, 25 X 1998. 
Wielikosielec OP, proboszcz parafii Podwyższenia Świętego Krzyża w Baranowiczach ${ }^{35}$.

Pragnieniem kard. Kazimierza Świątka było otwarcie Międzydiecezjalnego Wyższego Seminarium Duchownego w Pińsku, dla kształtowania przyszłych kapłanów. Dnia 12 września 2001 roku dokonał uroczystego otwarcia Seminarium Duchownego w Pińsku ${ }^{36}$.

Dnia 4 grudnia 1999 roku archidiecezja mińsko-mohylewska doczekała się biskupa pomocniczego, którym został ks. Cyryl Klimowicz ${ }^{37}$.

Wielkim wydarzeniem dla Kościoła na Białorusi było ustanowienie przez papieża Jana Pawła II witebskiej diecezji, które miało miejsce 13 października 1999 roku. Biskupem diecezji witebskiej mianowany został ks. Władysław Blin ${ }^{38}$, proboszcz parafii Wniebowzięcia Najświętszej Maryi Panny i św. biskupa Stanisława w Mohylewie. Jego konsekracja odbyła się w Witebsku 20 listopada 1999 roku, w jedynej w tym mieście ocalałej z sowieckich represji świątyni katolickiej pw. św. Barbary, dziś wyniesionej do godności katedry. Głównym konsekratorem był metropolita mińsko-mohylewski - ks. kard. Kazimierz Świątek, a współkonsekratorami - nuncjusz apostolski na Białorusi abp Dominik Gruszowski i biskup grodzieński Aleksander Kaszkiewicz. Sukcesję apostolską przez nałożenie rąk przekazali pasterzowi Kościoła witebskiego także inni obecni na uroczystości biskupi z Białorusi, Polski, Litwy, Łotwy, Rosji i Ukrainy.

Obecna była także liczna reprezentacja przedstawicieli Kościoła prawosławnego z władyką witebskiej eparchii - abp. Dymitrem. Egzarcha patriarchatu moskiewskiego na Białorusi, metropolita Filaret, nadesłał na tę okazję pismo, zredagowane po rosyjsku. Stwierdzając, że ustanowienie nowego biskupa, zawsze jest wielką radością dla Kościoła, napisał m.in. do bpa Blina:

Opatrzność Boża powołała Was do budowania diecezji w mającym długie dzieje Witebsku, gdzie obok siebie żyją od dawna prawosławni i katolicy, tak że nierzadko nasze Kościoły obejmują posługą duszpasterską te same rodziny i wzmagają się z bardzo podobnymi problemami.

${ }^{35}$ M. Komracka-Lipowska, M. Koprowski, Sakra biskupa Wielikosielca, „Gość Niedzielny" nr 28, 11.07.1999, s. 7.

${ }^{36}$ K. Świątek, List na otwarcie seminarium w Pińsku, „Niedziela” nr 37, 16 IX 2001, s. 25

${ }^{37}$ Notatka redakcyjna, Konsekracja bp. Klimowicza w Mińsku, "Gość Niedzielny” nr 51-52, 19-26 XII 1999, s. 7

${ }^{38}$ G. Grachowska, „Ave Maria” nr 8-9 (34-35), 1997, s. 12-17. 
Są to: religijna obojętność większości społeczeństwa, moralny upadek, konieczność katechizacji i społecznego zaangażowania w niesieniu pomocy inwalidom, ludziom w podeszłym wieku i młodzieży ${ }^{39}$.

Życie religijne $\mathrm{w}$ tej diecezji, jak mówi ks. bp Blin, rozpoczyna się od początku:

Większość spośród 1,5 mln mieszkańców dotychczas żyła tak, jak by Boga nie było. Ateizacja zniszczyła nie tylko Kościół, ale i człowieka. Białorusini muszą zrozumieć istotę przynależności narodowej. Nowe akty prawne z początku lat dziewięćdziesiątych dały każdemu obywatelowi prawo swobodnego wyboru przynależności do organizacji religijnej. Kościoły i organizacje religijne posiadają osobowość prawną po ich zarejestrowaniu przez odpowiednie władze. Obecna sytuacja jest jednocześnie i trudna, i piękna. Trudna - bo sfera wszystkich działań rodzi się od podstaw, piękna - bo nasz trud ma kształt miłości ${ }^{40}$.

Są jeszcze w Kościele witebskim różne potrzeby, ale najważniejsze, by w diecezji była wystarczająca liczba kapłanów i sióstr zakonnych, a także odpowiednia liczba kościołów. To w głównej mierze stworzyłoby warunki do pozyskiwania wiernych i coraz bardziej wszechstronnego rozwoju duszpasterstwa: powstania nowych wspólnot, ruchów, stowarzyszeń, w konsekwencji zaś do podnoszenia jakości życia wszystkich mieszkańców diecezji ${ }^{41}$.

Na zakończenie opisu sytuacji budowy struktur kościelnych trzeba tutaj przypomnieć słowa kard. Kazimierza Świątka, które wypowiedział w homilii do wiernych w kościele św. Szymona i Heleny w Mińsku podczas kanonicznej wizytacji: „Mówię wam: Kościół żyje, Kościół rozwija się, Kościół odmładza się"42.

${ }^{39}$ Z. Szuba, Konsekracja pierwszego biskupa witebskiego, „Niedziela” nr 49, 05 XII 1999, s. 13.

${ }^{40}$ W. Karasiński, Piękno jest ksztattem miłości, „Niedziela” nr 6, 11 II 2001, s. 15.

${ }^{41}$ W. Blin, Raczej pomagać niż przewodzić, „Ład Boży” nr 6 (872), jako dodatek do Niedzieli 06.02.2000, s. 3.

${ }^{42}$ U. Caryka, Kościót żyje, Kościót rozwija się, Kościót odmtadza się, „Ave Maria” nr 12 (67) 2000, s. 24. 


\section{SYNOD KOŚCIOŁA BIAŁORUSKIEGO JAKO WYRAZ SAMODZIELNOŚCl KOŚCIOŁA LOKALNEGO}

Jednym z ostatnich akcentów odrodzenia Kościoła na Białorusi, było zwołanie Synodu archidiecezji mińsko-mohylowskiej i diecezji pińskiej, który miał przyczynić się do samodzielności Kościoła lokalnego na Białorusi. Dnia 25 marca 1996 roku, w Uroczystość Zwiastowania Pańskiego, ksiądz kardynał Kazimierz Świątek, życząc wszystkim, aby Kościół na Białorusi wszedł w trzecie tysiąclecie odnowiony, podpisał dekret o zwołaniu pierwszego diecezjalnego Synodu w katolickim Kościele na Wschodzie ${ }^{43}$.

Dnia 28 wrzesień 1996 roku w uroczystej Mszy św., w Mińskiej katedrze kardynał Kazimierz Świątek dokonał otwarcia Synodu Kościoła Katolickiego, obejmującego archidiecezję mińsko-mohylewską, diecezję pińską, a od 25.11.1999 roku nową diecezję witebską.

W dniach 29-30 września 1997 roku w Mińsku odbyła się pierwsza sesja plenarna, poświęcona „Powołaniu i posłannictwu wiernych świeckich w Kościele i świecie”, a której celem było wzbogacenie osobistej wiedzy religijnej o godności człowieka, umocnienie w wierze, dzięki łasce związanej z prawdą o godności człowieka ochrzczonego, a także ożywienie miłości do Boga, Kościoła i człowieka ${ }^{44}$.

Na II Sesji Plenarnej w Baranowiczach (2-3 marca 1998 r.), Synod podjął temat "Małżeństwo i Rodzina”. Zasadniczym celem tej sesji było podjęcie jeszcze więcej pomocy i obrony rodziny, stworzenia duszpasterstwa rodzin, dążenia do tego, aby rodzina była otwarta na potrzeby innych osób, rodzinnych i kościelnych wspólnot, na potrzeby Kościoła, społeczeństwa oraz państwa, ponieważ rodzina po ludzku i po chrześcijańsku pomaga sobie i innym nieustannie wzrastać $\mathrm{w}$ wierze, nadziei i miłości - aż do poświęcenia.

Tematem „Powołanie do kapłaństwa i formacja stała kapłanów” rozpoczęła się w archikatedrze Wniebowzięcia NMP i Biskupa-Męczennika w Mohylewie (11-12 września 1998 r.) III Sesja Plenarna Synodu. Kolejna sesja Synodu, jak i dwie poprzednie, rozpoczęła się Mszą św. koncelebrowaną przez kardynała Kazimierza Świątka i kilkudziesięciu kapłanów ${ }^{45}$.

43 Dekret o zwołaniu Synodu, Dialog 5/27, 1996 s. 4.

44 "Materiały Synodalne”, nr 3 Mińsk-Pińsk 1997, s. 2-3.

45 „Materiały Synodalne”, nr 4 Mińsk-Pińsk 1998, s. 3. 
Kolejne dwa tematy: „Instytuty Życia Konsekrowanego w parafii” i „Dzieło misyjne Kościoła” zostały podjęte na IV sesji Synodu Plenarnego, która odbyła się w Baranowiczach 15-16 stycznia 1999 roku pod hasłem „Wy jesteście światłością świata”. Celem rozważań sesji było to, aby Synod przyczynił się do ożywiania świadomości wiernych obu wspólnot diecezjalnych, a także ludzi pośród których oni żyją, że ideał życia konsekrowanego jest najściślej związany ze świętością i misją Kościoła oraz że stanowi jego niezbywalny i konstytutywny element, ponieważ wyraża on samą jego naturę i bierze swój początek w Ewangelii ${ }^{46}$.

Następnie Synod przyczynił się do uświadomienia wiernym, że Kościół na Białorusi jest terenem misyjnym, którym się stał nim w wyniku działań systemu ateistycznego przez 70 lat. Wierni obciążeni balastem przeszłości nie są przystosowani do znalezienia się i działania jako autentyczni chrześcijanie. Trwający przez dziesiątki lat system, pod hasłem rozdziału Kościoła od państwa, usiłował tworzyć społeczeństwo bez Boga, bez religii. System ten eliminował inspirację religijną z publicznych sfer życia takich jak: piśmiennictwo, malarstwo, muzyka oraz wszelkie działania społeczne. Względem „opornym” albo domniemanych „opozycjonistów" stosowano wszelkie dostępne środki: aresztowania, zsyłki, degradację społeczną, propagandę i wymuszanie bezbożnego stylu bytowania i działania. Działalność tego typu wycisnęła swoje piętno na mentalność i nawykach ludzi oraz funkcjonowaniu instytucji. Dla wielu stało się rzeczą oczywistą, że nie należy wychylać się poza "płot” swojej egzystencji. To „ciśnienie” ideologicznie i politycznie ukształtowało społeczeństwo tak, że powinno być objęte "nową ewangelizacją" albo „reewangelizacją".

Ostatnim zadaniem było, aby Synod przyczynił się do kształtowania świadomości misyjnej poprzez nauczanie, wznawianie lub zakładanie i prowadzenie w duszpasterstwie Papieskich Dzieł Misyjnych ${ }^{47}$.

Dnia 21-22 czerwca 1999 roku w Bobrujsku odbyła się V Sesja Plenarna Synodu, która była poświęcona liturgii, budownictwu sakralnemu, roli sanktuariów w życiu Kościoła. Celem tej Sesji było rozważanie nad poprawieniem zrozumienia liturgii w Kościele przez wierzących. Rozważano też nad środkami materialnymi budowy kościołów. V Sesja

\footnotetext{
46 „Materiały Synodalne”, nr 6, Mińsk-Pińsk 21 IX 1998, s. 3-4.

47 „Materiały Synodalne”, nr 6, Mińsk-Pińsk 21 IX 1998, s. 5
} 
Synodu pokazała, że Kościół na Białorusi rozwija się i umacnia duchowo i materialnie ${ }^{48}$.

Następnymi tematami Synodu były tematy dotyczące chrześcijańskiej formacji młodzieży, charytatywnego duszpasterstwa specjalistycznego oraz duszpasterstwa ludzi pracy (VI Sesja Synodu, Baranowicze 22-23 lutego 1999); poruszono także tematy dotyczące przepowiadaniu Bożego Słowa, prowadzenia katechezy we wszystkich parafiach nie tylko wśród dzieci i młodzieży, lecz także i wśród ludzi starszych, która ma doprowadzić do pogłębienia i zrozumienia życia religijnego, do pobudzenia odpowiedzialności za swoją parafię oraz za cały Kościół (VII Sesja Synodu, Homel 25-26 listopada 1999). Kolejne tematy dotyczyły środków masowego przekazu, problemu sekt i nowych ruchów religijnych $\mathrm{w}$ duszpasterstwie oraz wewnętrznej strukturze archidiecezji mińsko-mohylewskiej, witebskiej i pińskiej. W Witebsku była ostatnia VIII sesja Synodu, 14-15 czerwca 2000 roku. $^{49}$ Poruszono tematy dotyczące jedności chrześcijan i działań ekumenicznych.

Dnia 30 września 2000 roku w katedrze w Mińsku odbyło się uroczyste zakończenie Synodu archidiecezji mińsko-mohylewskiej oraz diecezji pińskiej i witebskiej. Mszy św., zamykającej to wydarzenie, przewodniczył osobisty wysłannik Jana Pawła II - kard. Camillo Ruini. Plonem Synodu jest 17 zatwierdzonych dokumentów, tzw. statuty, dla trzech diecezji, w których toczyły się obrady ${ }^{50}$.

\section{ZAKOŃCZENIE}

Urzeczywistnianie się Kościoła dokonuje się „tu i teraz" na drodze realizacji podstawowych funkcji: nauczycielskiej, liturgicznej i pasterskiej. „Misja Chrystusa Odkupiciela, powierzona Kościołowi, nie została jeszcze [...] wypełniona do końca. Gdy u progu trzeciego tysiąclecia od Jego przyjścia obejmiemy spojrzeniem ludzkość, przekonamy się, że misja Kościoła dopiero się rozpoczęła i że w jej służbie musimy zaangażować wszystkie nasze siły" (RM 1).

${ }^{48}$ Notatka redakcyjna, Synod archidiecezji mińsko-mohylewskiej $i$ diecezji pińskiej, „Gość Niedzielny" nr 27, 04.07.1999, s. 7.

${ }^{49} \mathrm{~S}$. Pawlina, W dziesiata rocznice utworzenia struktur diecezjalnych, "Przegląd Pińskiej Diecezji" nr 3 (21), 2001, s. 34.

${ }^{50}$ Notatka redakcyjna, Zakończenie Synodu w Mińsku, "Niedziela” nr 42, 15 X 2000, s. 25. 
Trzeba zatem, aby w dziele ewangelizacji ciągle odwoływać się do Chrystusa, jedynego naszego wzoru. Do aktywnego zaangażowania $\mathrm{w}$ to dzieło mobilizować nas mają nie tylko okoliczności, w jakich przyszło nam żyć, ale nade wszystko gorąca miłość do Chrystusa i Kościoła.

Współczesna ewangelizacja, jeżeli chce być wierna Chrystusowi, ma kierować się miłością pasterską, mającą na celu dobro człowieka - jego zbawienie. Tylko ta miłość może sprawić, że wszelkie nasze poczynania ewangelizacyjne i duszpasterskie będą osadzone na trwałym fundamencie. Ona również jest motywacją wszelkich inicjatyw pastoralnych, zwłaszcza tych, od których zależy dzisiaj rozwój Kościoła i doskonalenie społeczności ludzkiej.

Streszczenie. Urzeczywistnianie się Kościoła dokonuje się „tu i teraz” na drodze realizacji podstawowych funkcji: nauczycielskiej, liturgicznej i pasterskiej. Jesteśmy świadomi tego, że misja Chrystusa Odkupiciela, powierzona Kościołowi, nie została jeszcze wypełniona do końca. Sytuacja Kościoła katolickiego na Białorusi po upadku ZSRR w 1991 roku uległa zmianie. Wierni mogli wreszcie wyjść z podziemia do sfery publicznej. Ważnym krokiem było ustanowienie struktur administracji i hierarchii kościelnej. Erygowano nowe parafie, księża i katechiści z zagranicy mogli przyjeżdżać, by głosić Ewangelię. Co rok podejmowane są nowe wysiłki, zajęcia, aktywności, które angażują wiernych. Ważnym znakiem świadczącym o rozwoju i dojrzałości lokalnego Kościoła był Synod Kościoła na Białorusi, odbywający się w latach 1996-2000.

Słowa kluczowe: Białoruś; Kościół; ewangelizacja.

Abstract. The Church in Byelorussia and her experience of faith after 1991. The Church's self understanding of itself is present in its three-fold mission: teaching, liturgy, and pastoral activity. The Church is called on through this mission to continue the work of Christ the Redeemer who has come on earth. His kingdom is present but it is still to be fully realized - the Church continues to proclaim the Kingdom until he comes in glory. Like many places throughout the world, Byelorussia continues to be a place in which the mission of the Church goes on. The situation of the Catholic Church in Byelorussia changed after the fall of the Soviet Union in 1991. The faithful were free to move from being an underground Church to profess publicly their faith. An important step was taken with the erection of administrative structures and the restoration of the hierarchy. New parishes were established and priests and catechists from oversees could arrive to preach the Gospel. Each year new religious activities that gather the faithful together are in evidence. An important sign of this development and independence of ecclesiastical life in Byelorussia was the synod of the local Church held between 1996-2000.

Keywords: Byelorussia; Church; Evangelization. 